\title{
Exploration on the Cultivation of Prefabricated Interior Decoration Technical Talents Based on Mode of Integration of Industry and Education
}

\author{
Xiuyun Li \\ School of Construction Engineering, Guangzhou Nanyang Polytechnic College, Guangzhou Guangdong, 510925, China \\ *Corresponding author. Email: sueone921@163.com
}

\begin{abstract}
Prefabricated interior decoration technical talents are in short supply with the trend of construction industrialization and there is an urgent need to improve the overall technical level. The local vocational colleges are based on professional construction, based on the mode of Industry-Education integration and collaborative education, analyze the current situation of prefabricated interior decoration technical talents under the background of new engineering, and put forward suggestions for cultivating prefabricated interior decoration technical talents, which provides a reference for practice.

Keywords: integration of industry and education, prefabricated interior decoration technical talents,
\end{abstract}

cooperative education

\section{INTRODUCTION OF NEW ENGINEERING AND BUILDING ASSEMBLY TALENTS}

The state has proposed a series of major strategies such as Made in China 2025 and new-type urbanization to actively respond to a new round of industrial change. During the implementation of major projects, the concept of "people's skills, nation's weapons" is strengthened, highlighting the function of vocational education. In 2017, China Education initiated the construction of new engineering disciplines, and proposed the goal of building a strong country in engineering education by 2020,2030, and 2050, and gradually building a vision of becoming a world engineering innovation center and talent highland. In 2018, the Ministry of Education of China accelerated the implementation of new engineering disciplines, requiring universities to accelerate the cultivation of new engineering and technology talents, and some universities opened new engineering majors, and actively carry out education layout for future strategies. In 2019, with the surge in the demand for engineering talents in the ethnic support industry and the introduction of high salaries, college specialties in the new engineering disciplines continue to be popular. "New Engineering" introduces new concepts, new elements, new ideas and new models on the basis of traditional engineering majors. At the same time, "New Engineering" provides new talent training goals for higher education, strives to cultivate new talents with sustainable competitiveness[1], and then promote the upgrading and optimization of industrial structure, and actively adapt to the development needs of the new economy.
In the process of promoting the industrialization of construction, China has decided to vigorously develop prefabricated buildings and promote the adjustment and upgrading of industrial structure since 2016. Under the guidance of policies, the training of diversified and innovative strategic engineering talents requires that engineering education must be closely linked to industrial development. Prefabricated buildings have the advantages of seismic performance, fire prevention, waterproof, antifreeze, crack prevention, moth proof and anti-aging. It integrates diversified design, production industrialization, construction assembly, decoration integration, management information, and intelligent operation, and strives to the quality of green, safe, healthy, comfortable and beautiful building spaces. As the future space will be deepened with the concept of building houses with technology, assembled interior decoration talents should follow up synchronously, but there is still a lack of a large number of assembled construction technicians and corresponding industrial workers. At present, most of the skills of assembled technicians and teams are derived from the accumulated experience of traditional manual construction. For new assembled construction methods, continuous training is required to actively improve the overall skills.

\section{ADVANTAGES OF THE PRODUCTION- EDUCATION INTEGRATION AND COLLABORATIVE EDUCATION MODEL}

Prefabricated buildings are one of the major new engineering disciplines, which not only upgrades the traditional engineering education, but also serves the regional related emerging industries. The representative 
system of vocational education with industry-education integration includes the German model, Japanese model, Australian model, British model, American model, and French model, all of these modes have played a leading role in school enterprise cooperation or government driven cooperation. The mode of enterprises' extensive participation in vocational education has very successfully promoted the local economy to leap forward, and the social economy has made great progress and made it in the leading position in the world.

The Ministry of Education of China also pointed out that integration of industry and education is the future trends; for cooperative education, with industry as the support and education as the core; and for school enterprise cooperation, with school as the leader and enterprise as the foundation[2]; so integration of industry and education is forming the main theme of future vocational education. The integration of industry and education and cooperative education model has multiple advantages: First, in that training mode, making use of market information and docking with post standards is conducive to help enterprises find suitable talents and reserve human resources; second, vocational schools gather enterprise resources, gradually get familiar with practical tasks, and improve the comprehensive ability of application-oriented, which is conducive to the enterprise's immediate employment and cost savings; third is to enhance the effectiveness of production, education and research, which is conducive to the incubation of achievements of both sides and serves the local economy.

\section{SUGESTIONS ON CULTIVATING PREFABRICATED INTERIOR DECORATIION TECHNICAL TALENTS IN THE MODE OF INTEGRATION OF INDUSTRY AND EDUCATION}

\subsection{Establish a cooperative education system}

Vocational education focuses on the application of skills. Many years of practice in many parts of the world have proven that school-enterprise cooperation is a very important and effective way to cultivate applied talents. Prefabricated interior decoration is an emerging technology in the construction market. During the training of school-enterprise cooperation in assembled interior technology talents, vocational schools and enterprises should establish a cooperative education system to clarify the rights, obligations and corresponding responsibilities of schools, enterprises, students, and other parties. Drawing on the useful experience of various places, many vocational colleges are led by local governments and have established regional industry vocational education steering committees, where a number of companies have gathered to brainstorm development strategies and teaching reforms in vocational schools to further meet the talent needs of enterprises.

Some scholars have also pointed out that the development of vocational education needs to reform measures such as multiple admissions and comprehensive quality evaluations, which coincides with the talent reserve strategies of many enterprises. Some vocational colleges take the initiative to cultivate talents together with enterprises, actively accept industry guidance, rely on industry development, in the process of vocational school enrollment, both schools and enterprises jointly enroll, sign enrollment applications, practical agreements and employment agreements with enterprises. According to service agreements, enterprises fully support the return of students' tuition fees for students who have been in school for many years, and support further education. At the same time, when implementing a preferential training system, the number of student sources should be considered. For some small and medium-sized enterprises, paying high tuition fees for three years of vocational education requires active measures from vocational schools. The focus of the company's attention lies in a small class (under 30 people) with the same professional orientation of assembled interior technology. Based on the number of enterprise bookings, integrating 1-3 enterprise joint training, sharing the cost, reducing the cost pressure, and finally harvesting the target oriented talents.

\subsection{Plan training programs, integrate and share resources}

One of the training objectives of vocational schools is to deliver high-quality talents to serve local economic development. The training plan for vocational schools is the standard for talent training and the basis for ensuring development of professional teaching. The applicationoriented personnel training programs in developed countries have the characteristics of emphasizing practice, breakthrough-based courses, and interdisciplinarity, which are worth learning from[3]. For example, Germany's dualtrack training program system and Australia's competency-based TAFE college vocational education training program all attach great importance to the results of technical education. The form of the training program is very flexible and diverse, which is conducive to employment and lifelong education.

Nowadays, many vocational colleges have established a stable teaching mode of integration of industry and education. Before the beginning of each school year, an action plan is launched. Special attention is paid to inviting enterprises and industry representatives to participate in the development of education and training plans. For example, when some vocational colleges in Guangzhou make overall arrangements for teaching in the new school year, they first gather teachers, prepare a preliminary plan for the training of prefabricated building talents according to the development trend of the building, and then invite corporate experts, senior engineers, project managers and 
other representatives come together for demonstration, so as to express their own opinions and revisions on the details of the entire talent training plan (Figure 1).

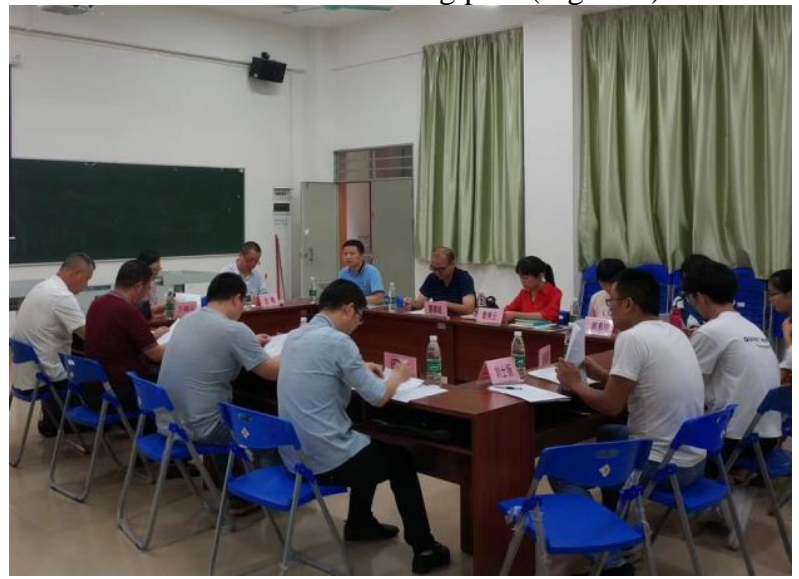

Figure 1. Schools and enterprises arrange talent programs In the first half of 2019, new engineering colleges and universities proposed that the construction of gold medal specialty, gold medal curriculum and highland construction plan are beneficial measures for talent cultivation, and promote first-class curriculum education. Vocational colleges focus on cultivating applicationoriented high-quality talents, and also follow the pace to launch corresponding education activities. At present, some vocational colleges lack of assembly sites. Therefore, in the process of formulating prefabricated interior decoration technical talents training plan, it should actively integrate the available resources of the enterprise and establish a real working environment to ensure the smooth implementation of the talent training plan. For example, taking Guangzhou Nanyang Polytechnic College as an example, during the training of prefabricated interior decoration technical talents, on-site installation training and acoustic simulation tests were conducted using the construction assembly studio of the school-enterprise cooperation unit Guangdong Meisui Industrial Development CO.,LTD.(Figure 2). The teaching method is flexible, and the enterprise standards and operating procedures are connected. Resource sharing overcome the shortcomings of closed teaching within the school, making the talent training program come to fruition.

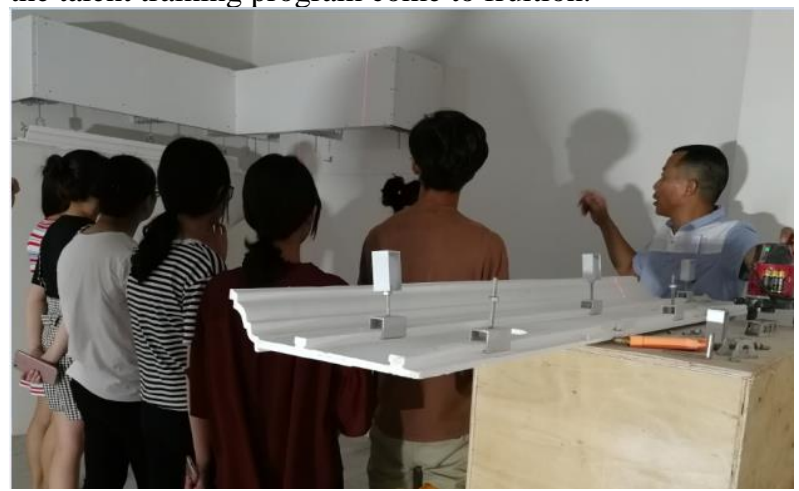

Figure 2. On-site construction training for prefabricated interior technology

\subsection{Teacher training of prefabricated building}

The "double-competency" teaching faculty is the core strength and important guarantee for the teaching and implementation of prefabricated interior decoration technical talents. Vocational colleges focus on training applied talents, which requires students to have proficient practical skills in a real work environment. In practice, school teachers or corporate trainers should put modular teaching into real cases and tasks. If students could learn from the practice, they need to teach by means of apprentices, and present every step of the assembled practical exercises. In this way, students can intuitively absorb and understand the key points and difficult points of practice, and better build a sense of achievement in acquiring skills. Most of the enterprise trainers have high skills, but their explanation and interpretation ability is not strong. In addition, the problem of difficult to unify the training time due to the heavy task of the company, then it is necessary to strengthen the training of school teachers, and then find an efficient talent training path.

The government and the market are important forces to promote the integration of production and education. The governments of many cities have actively implemented policies for the development of prefabricated buildings and further promoted the skills of prefabricated building teachers. For example, in order to improve and cultivate the overall quality of the workers in the prefabricated construction industry, the Guangzhou Municipal Government actively implements the "Opinions of the state council on implementing the lifelong vocational skills training system" and "the opinions of Guangzhou on the implementation of vigorously developing prefabricated buildings to accelerate the modernization of the construction industry". In July 2019, a training course for prefabricated construction industry workers was launched. The government has recruited skilled construction workers, technicians, and construction vocational college teachers to conduct modular learning and closed practical operations of component assemblers and workers. Practical skills module training and professional literacy module training are very effective in improving the level of teacher skills.

\subsection{Strengthen professional ideological and political construction}

Under the guidance of the world, life and values outlook, professional construction can make comprehensive progress in the correct direction. The new talent training model of the integration of production and education requires universities to integrate the concept of "cooperative education" into the whole process of moral education, so that college students have professional skills and personal qualities which meet social needs, and make contributions to social and economic development[4]. The combination of scientific ideas and ideological and political content makes the project-based case or modular 
curriculum design hierarchical, and the integration of part of the story telling narrative learning method, which is conducive to an active atmosphere and physical and mental pleasure. The teacher's preaching and deeds teach the students to see and demonstrate where they are and be good at thinking and extending. Also the process let them subconsciously realize the truth, germinate and innovate, and act intentionally.

The course of prefabricated interior decoration technology should be integrated with the elements of ideological and political theory, the concept of educating people should be integrated into the professional knowledge system, act in the same direction so as to form a synergistic effect. Construct a green and environmental building space, make the the site in an orderly and bright manner, and become a quasi-professional full of positive energy and sense of accomplishment. For example, prefabricated interior decoration technology can be combined with the themes of global climate, ecological environment, life and health, socialist core values, and cultural self-confidence, so that China's common ideals and beliefs can be merged with correct values and professional knowledge in order to penetrate morality and cultivate people. As a training instructor, lead by example to guide students in the process of explaining every detail, learn to listen, and learn to ask questions, so that students can clear the testing site after work, practice professional ethics, and carry forward outstanding craftsmen spirit.

\subsection{Cultivate characteristic bases, promote industry-university-research collaboration}

In the process of promoting the integration of industry and education, many vocational colleges have actively established cooperation platforms, bases and studios inside and outside the school with enterprises, which is undoubtedly a new form of cooperative education. The construction of the production-education integration platform is to promote the participation of multi-subject knowledge, technology, management and even capital factors in the construction of new engineering[5]. The practice base of college students outside the school is conducive to the industry entry experience of the course, which intuitively feels the professional orientation; and the enterprise curriculum development, apprenticeship training and post-employment internships in the semester are the main practical ways. With the sharing of resources and the depth construction of the base, on the one hand, it allows students to harvest accurate prefabricated interior decoration technical talents to deepen their technical research or promote their academic qualifications; on the other hand, it strengthens the education function of the industry-university-research platform, backed by disciplines, and promotes new engineering disciplines to lead new technology, encourage students to research and transform inventions, and serve the new industries development. Meanwhile, build a characteristic base and form a scientific atmosphere, so that students have a clear career plan, cultivate a sense of belonging and happiness, and better promote the economic development of the enterprise, serve and give back to the society.

\section{CONCLUSION AND PROSPECT}

With the current rapid development of science, technology and economy, new requirements are put forward for prefabricated interior decoration technical talents under the background of new engineering. Colleges and universities are an important position for the training of construction assembly technical talents and industrial technical workers. Under the correct guidance, the fundamental task of cultivating people with morality is well implemented. Also it should cultivate application-oriented technical personnel with both ability and morality and high skills. Various measures to formulate preferential policies, put schoolenterprise cooperation into social responsibility reports, and develop educational enterprises will motivate the enthusiasm of business community to participate in vocational education[6]. The mode of integration of industry and education and collaborative education is suitable for the cultivation of assembly interior decoration technical talents, which is worth popularizing, while the distinctive, obvious advantage and sustainable development of production-education integration and collaborative education is still being explored and deepened; Education, as a powerful backing for the economic take-off, needs to make great efforts to build an application-oriented technical quality team and gradually realize the dream of becoming the flourishing states through the thriving of education.

\section{ACKNOWLEDGMENT}

This work was supported by Research on the 2019-2020 Vocational Education Teaching Reform of the Teaching Working Committee of the Chinese Vocational and Technical Education: "Exploration and Practice of the Integrative Production and Education Model of Green Assembly Interior decoration Technology and Construction Specialty under the background of new engineering"(1910159); 2019 College's scientific research project of Guangzhou Nanyang Polytechnic College, "Exploration and Application of Upgrading Medical Space Roof Wall System Based on Prefabricated Interior Decoration Technology"(NY-2019KYYR-31); Guangdong Provincial Department of Education Research Platform fund: "Green and Environmental-friendly Residential roof Modular Design and Research on the application of integrated assembly" (2017GkQNCX 126) 


\section{REFERENCES}

[1] Wang Ruijin. Construction and exploration of Internet security virtual simulation practice teaching for new engineering. Experimental Technology and

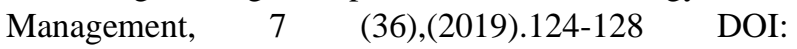
10.16791/cnki.sjg.2019.07.030

[2] Chai Wei, Liu Bozhi. Education at the two sessions. Chen Baosheng, Minister of education, answers questions both Chinese and foreign journalists. China

Education Daily, March 17,(01)

2018.DOI:http://paper.jyb.cn/zgjyb/html/2018-

03/17/content_495845

[3] Yao Yao. Research on the countermeasures of training applied talents in local undergraduate colleges under the background of new engineering. Journal of Zhongzhou University, (03)(2019) 1-6. DOI: http://kns.cnki.net/kcms/detail/41.1275.G4.20190702.1 045.002.htm1

[4] Xing Qiana. Research on the path of moral education of college students under the background of industry-education integration. Journal of Dezhou University,02 (2019) 86-89. DOI:10.3969/j.issn.10049444.2019.02.020

[5] Li Yuqian. Construction of integrated productioneducation fusion platform for emerging engineering- from an incomplete contract perspective. China higher education research, 03(2018) 38-43. DOI:10.16298/j.cnki.1004-3667.2018.03.08

[6] Wang Hui, The exploration of the development American upgraded vocational education system. International Comparative education, 38 (3)(2016) 8995. DOI: CNKI:SUN:BJJY.0.2016-03-014 